\title{
K-Ar age determinations of late Tertiary and Quaternary Andean volcanic rocks, Southern Peru
}

\author{
ICHIRO KANEOKA ${ }^{1}$ and CARLOS GUEVARA ${ }^{2}$ \\ Geophycial Institute, Faculty of Science, University of Tokyo, Bunkyo-ku, Tokyo 113, Japan ${ }^{1}$ and \\ Institute of Geology, Mineralogy and Metallurgy (INGEMMET), Lima, Peru ${ }^{2}$
}

(Received December 12, 1983: Accepted March 12, 1984)

\begin{abstract}
$\mathrm{K}$-Ar ages were determined on 30 Andean volcanic rocks from southern Peru, most of which were considered to belong to the Barroso Group of Quaternary in age. The results have revealed, however, that their ages range from late Miocene to recent ( 7.2 to less than $0.03 \mathrm{Ma}$ ). This indicates that the Barroso Group samples might include much wider age ranges than had been assigned. Relatively young volcanic activity of late Quaternary is apparently restricted in the northwestern part including the vicinity of Arequipa in the investigated area. The main volcanic activity in the southwestern part seem to have almost ended by early Pleistocene. The shoshonitic rocks which are located around the Puno area probably extruded about $6 \mathrm{Ma}$ ago in a relatively short period of less than a few hundred thousand years.
\end{abstract}

\section{INTRODUCTION}

Concerning the period of volcanic activities in the Andean volcanic zone, some investigators studied it by applying radiometric dating (e.g., BALLON and LEFÈVRE, 1976; WeIBEL et al., 1978). DRAKE (1976) has revealed that there are some differences in the period of volcanic activities from north to south in the Andes. His results suggest that volcanic activities were limited in the region with the latitude of about $30^{\circ} \mathrm{S} 50$ to $60 \mathrm{Ma}$ ago. In the southern Chile, the volcanic activity already started about 40Ma ago. However, in the central Andes the volcanic activity seems to have become intense since about $25 \mathrm{Ma}$ ago. BAKER and FRANCIS (1978) summarized the data on the ages of volcanic rocks from the central Andes by comparing them to those of samples from the central Oregon and assigned the main volcanic activities to be around 20-25, 10 and 5 Ma ago. NoBlE et al. (1974) demonstrated a possibility of the correlation between the Andean volcanic and tectonic activities since Tertiary. Although they determined the ages of only seven samples by themselves, they also identified a relatively intense volcanic activity in the southern Peru area about $12 \mathrm{Ma}$ ago together with that of about 40-50Ma ago on the basis of compiled data of the radiometric ages. STEWART et al. (1974) reported more than $60 \mathrm{~K}-\mathrm{Ar}$ ages on the Andean rocks from Peru, which ranged from 27 to $679 \mathrm{Ma}$, but those rocks were mostly plutonic and metamorphic rocks.

On the other hand, BAKER (1977) pointed out a possible migration of volcanic activities in the central Andes from west to east. FARRAR et al. (1970) also identified a similar migration of the ages for igneous rocks. However, a reverse trend was reported for recent volcanic activities (THORPE and FRANCIS, 1979). In effect, the youngest volcanic activity occurs along the western edge of the Cordillera Occidental. SCHWAB and LIPPOLT (1976) reported that the andesitic volcanic activity became remarkable about $10 \mathrm{Ma}$ ago. In the southern Peru area, the activity of ignimbrite was identified to have occurred about $25 \mathrm{Ma}$ ago (TOSDAL et al., 1979).

As shown above, most dated rocks in the Andes were of Tertiary in age. However, some radiometric age data have revealed that even the volcanic rocks which were assumed to be of Quaternary show the age of Tertiary (e.g., 
BELLON and LEFÈvRE, 1976). This demonstrates an example of the significance of radiometric dating. In the present study, $\mathrm{K}-\mathrm{Ar}$ ages were determined on 30 volcanic rocks, which were collected during the summer of 1980 by the scientific team on "Geochemical investigation of the central Andean volcanic zone" (Leader: NAOKI ONUMA) sponsored by the Overseas Scientific Research, Ministry of Education. These rocks were considered to belong to the Barroso Group of Quaternary in southern Peru. We have intended to examine the lateral variation of the young volcanic activity in southern Peru and to check the stratigraphically assigned ages on the basis of the K-Ar dating.

\section{STRATIGRAPHY AND SAMPLES}

The distribution of volcanic rocks in southern Peru is shown in Fig. 1. In this area, geological periods are classified as shown in Fig. 2, where Barroso, Sencca and Tacaza Groups are assigned to be the Cenozoic volcanic series. Among them, only Barroso Group is considered to be of Quaternary. Although pyroclastic deposits are identified in recent deposits, there are not so many examples which show the occurrence of volcanic rocks.

In this area, several cases were reported for recent volcanic activities. For example, Ubinus volcano, located to the east of Arequipa, is showing fumes or smokes since 1974 and recorded a great eruption in 1622. Huainaputina volcano also has a record of great eruption around 1600 (WEIBEL et al., 1978).

In the present study, most samples are volcanic rocks which are considered to belong to the Barroso Group except for one sample (A-166). The sample (A-166) is a dacite of the Sencca Group. However, the appearance of the exposure state for each sample was so different that we had no guarantee whether they were surely extruded less than $2 \mathrm{Ma}$ ago or not. In the present study, we selected samples in order to cover the wide area in southern Peru as much as possible. Samples were selected on the basis of the following criteria.

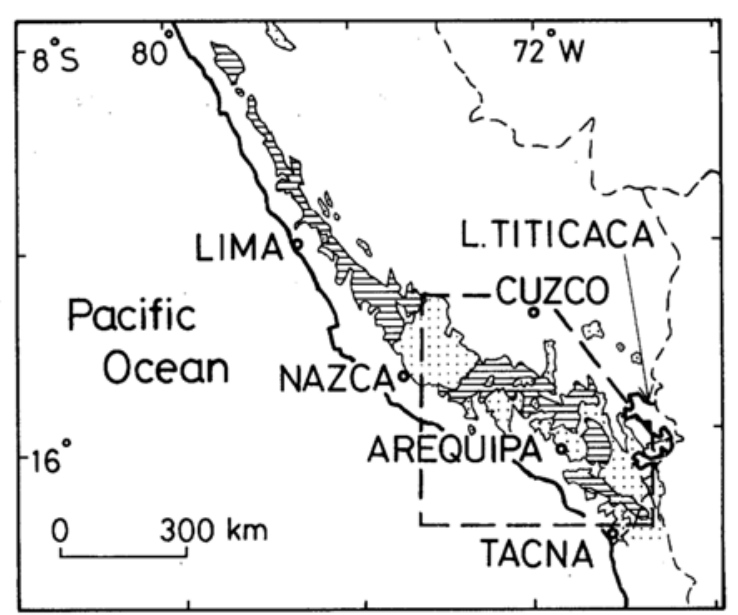

Fig. 1. Distribution of Cenozoic volcanism in southern Peru, central Andes. The investigated area is indicated by a broken line, where Arequipa and Cuzco are included.

Upper Miocene to Quaternary.

\section{Paleogene to lower Miocene.}

(1) A sample should be fresh as much as possible, showing no serious effects of secondary alteration or oxidation.

(2) A sample which contains large phenocrysts of more than a few $\mathrm{mm}$ in size should be discarded on the ground that such phenocrysts might include excess ${ }^{40} \mathrm{Ar}$.

(3) A sample should be large enough so that the fresh part in the interior of the sample can be used for $\mathrm{K}-\mathrm{Ar}$ dating.

The criterion (3) is required to remove the dirty surfaces in order to exclude the secondary effects. The criterion (1) is the most important requisite in the $\mathrm{K}-\mathrm{Ar}$ dating and each sample was examined carefully under macro- and microscopic observations in the present study. Although we tried to find fresh rocks as much as possible, some samples show signs of alteration to some extent. In such a case, the K-Ar age should be considered to show a lower limit for its formation age.

In Andean volcanic rocks, most of which are andesites and dacites, large phenocrysts of plagioclase or biotite with the size of more than a few $\mathrm{mm}$ are often observed. Since large 
phenocrysts are considered to have been formed in a magma reservoir, they are expected to contain the ambient gases in them, resulting in keeping some amount of excess ${ }^{40} \mathrm{Ar}$. Such noble gas components have been identified in large olivine and clinopyroxene phenocrysts (e.g., KANEOKA and TAKAOKA, 1980). Even plagioclase phenocrysts show the occurrence of excess ${ }^{40} \mathrm{Ar}$ in some cases (e.g., DAmon et al., 1967). Hence, it is very important to exclude such phases from samples for $\mathrm{K}-\mathrm{Ar}$ dating. However, it is not easy to separate them completely to exclude the fine fragments. Hence, only those which do not contain large phenocrysts of more than a few $\mathrm{mm}$ in size were used for K-Ar dating in this study.

\section{EXPERIMENTAL}

Samples were analysed as whole rocks. From the interior of each block sample, we cut

\begin{tabular}{|c|c|c|c|}
\hline \multicolumn{3}{|c|}{ STAGE } & FORMATION \\
\hline \multirow{8}{*}{$\begin{array}{l}\frac{U}{O} \\
\mathcal{U} \\
\bigcirc \\
Z \\
\cup \\
\cup\end{array}$} & \multirow{4}{*}{ 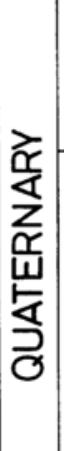 } & RECENT & $\begin{array}{l}\text { Alluvial deposits } \\
\text { Pyroclastic deposits }\end{array}$ \\
\hline & & \multirow{3}{*}{$\begin{array}{l}\text { PLEISTO - } \\
\text { CENE }\end{array}$} & $\begin{array}{l}\text { Morrains and } \\
\text { fluvial glaciers } \\
\text { Mud flows }\end{array}$ \\
\hline & & & BARROSO GROUP \\
\hline & & & Conglomerates \\
\hline & \multirow{4}{*}{ 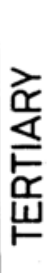 } & \multirow{2}{*}{ UPPER } & SENCCA GROUP \\
\hline & & & Millo Formation \\
\hline & & MIDDLE & TACAZA GROUP \\
\hline & & LOWER & $\begin{array}{l}\text { Sotillo Formation } \\
\text { Huanca Formation }\end{array}$ \\
\hline
\end{tabular}

\section{VOLCANIC}

Fig. 2. Schematic stratigraphic sequence in southern Peru, central Andes. The underlined groups indicate those composed of volcanic materials. the fresh part in the form of rectangle of about $10 \mathrm{~mm}$ in size. Among such rectangular samples, we selected a few pieces of about 2-3 $\mathrm{g}$ for $\mathrm{Ar}$ analysis and the remainders were powdered for $\mathrm{K}$ analysis.

$\mathrm{K}$ was analysed by a flame photometer with the $\mathrm{Li}$ internal standard method. For some samples, however, $\mathrm{K}$ contents analysed by the $\mathrm{X}$-ray fluorescence method by ARAMAKI (person. com.) were used for calculating $\mathrm{K}-\mathrm{Ar}$ ages. Before Ar extraction, the sample was preheated in vacuum at about $200^{\circ} \mathrm{C}$ for 12 hours to remove atmospheric Ar adsorbed on the surface of the rock. Ar was analysed on a Reynolds type mass spectrometer with a radius of $15 \mathrm{~cm}$. ${ }^{38} \mathrm{Ar}$ was used as a tracer for isotope dilution method.

$\mathrm{K}-\mathrm{Ar}$ ages were calculated by using the constants recommended by STEIGER and J̈̈GER (1977). K analysis included the uncertainty of $1-1.5 \%$ and $\mathrm{Ar}$ analysis those of about 0.5 and $0.2-0.3 \%$ for ${ }^{40} \mathrm{Ar} /{ }^{36} \mathrm{Ar}$ and ${ }^{40} \mathrm{Ar} /{ }^{38} \mathrm{Ar}$ ratios, respectively. The uncertainties in ages are calculated on the basis of these uncertainties together with the degree of atmospheric contamination.

\section{RESULTS AND DiscusSION}

The results of $\mathrm{K}-\mathrm{Ar}$ dating and sampling localities are summarized in Table 1 and schematically shown in Fig. 3. In the investigated area, only samples which meet the criteria described before were selected for $\mathrm{K}-\mathrm{Ar}$ analyses. One may argue that we might not always select typical samples from each site. However, they were chosen on the basis of common criteria from each site and we have never adopted any subjective preference in selecting samples for K-Ar dating. Hence, we can at least say that the results shown in Table 1 and Fig. 3 reflect some general tendency concerning their eruption ages.

In the present study, one of the most conspicuous results is that more than half of samples show ages which exceed $2 \mathrm{Ma}$, though they were collected as samples of the Barroso Group 
Table 1. K-Ar ages of volcanic rocks of Barroso Group in Southern Peru

\begin{tabular}{|c|c|c|c|c|c|c|}
\hline Sample No. & Location & Rock Type & $\begin{array}{l}{ }^{a)} \mathrm{K} \\
(\%)\end{array}$ & $\begin{array}{c}{ }^{40} \mathrm{Ar}_{\mathrm{rad}} \\
\left(\times 10^{-8}\right. \\
\left.\mathrm{cm}^{3} \mathrm{STP} / \mathrm{g}\right) \\
\end{array}$ & $\begin{array}{c}{ }^{40} \mathrm{Ar}_{\text {atm }} \\
40 \mathrm{Ar}_{\text {total }} \\
(\%)\end{array}$ & b) Age (Ma) \\
\hline $\begin{array}{l}\text { Characato area } \\
\text { CH-02 }\end{array}$ & $16^{\circ} 21.8^{\prime} \mathrm{S}, 71^{\circ} 17.6^{\prime} \mathrm{W}$ & Andesite & 1.94 & 50.72 & 94.4 & $6.71 \pm 0.57$ \\
\hline $\begin{array}{c}\text { Arequipa area } \\
\text { AR-07-02 } \\
\text { AR-17-02 }\end{array}$ & $\begin{array}{l}16^{\circ} 11.8^{\prime} \mathrm{S}, 71^{\circ} 40.7^{\prime} \mathrm{W} \\
16^{\circ} 21.1^{\prime} \mathrm{S}, 71^{\circ} 25.8^{\prime} \mathrm{W}\end{array}$ & $\begin{array}{l}\text { Andesite } \\
\text { Andesite }\end{array}$ & $\begin{array}{l}1.42 \\
2.18\end{array}$ & $\begin{array}{l}1.567 \\
0.657\end{array}$ & $\begin{array}{l}98.9 \\
99.1\end{array}$ & $\begin{array}{c}0.28 \pm 0.10 \\
0.078 \pm 0.035\end{array}$ \\
\hline $\begin{array}{l}\text { Chivay area } \\
\text { CV-07-01 } \\
\text { CV-08 }\end{array}$ & $\begin{array}{l}15^{\circ} 37.8^{\prime} \mathrm{S}, 71^{\circ} 36.1^{\prime} \mathrm{W} \\
15^{\circ} 34.4^{\prime} \mathrm{S}, 71^{\circ} 36.0^{\prime} \mathrm{W}\end{array}$ & $\begin{array}{l}\text { Andesite } \\
\text { Andesite }\end{array}$ & $\begin{array}{l}2.00 \\
2.37\end{array}$ & $\begin{array}{l}1.751 \\
0.871\end{array}$ & $\begin{array}{l}97.7 \\
97.5\end{array}$ & $\begin{array}{c}0.23 \pm 0.05 \\
0.095 \pm 0.009\end{array}$ \\
\hline $\begin{array}{l}\text { Cailloma area } \\
\text { CM-01 } \\
\text { CM-05-01 }\end{array}$ & $\begin{array}{l}15^{\circ} 16.3^{\prime} \mathrm{S}, 71^{\circ} 37.8^{\prime} \mathrm{W} \\
15^{\circ} 17.6^{\prime} \mathrm{S}, 71^{\circ} 49.8^{\prime} \mathrm{W}\end{array}$ & $\begin{array}{l}\text { Andesite } \\
\text { Andesite }\end{array}$ & $\begin{array}{l}1.74^{*} \\
1.76^{*}\end{array}$ & $\begin{array}{c}25.48 \\
0.414\end{array}$ & $\begin{array}{l}71.6 \\
99.9\end{array}$ & $\begin{array}{l}3.77 \pm 0.14 \\
0.06 \pm 0.23\end{array}$ \\
\hline $\begin{array}{l}\text { Orcopampa area } \\
\text { OP-01 } \\
\text { OP-11-01 } \\
\text { OP-14-02 }\end{array}$ & $\begin{array}{l}15^{\circ} 03.8^{\prime} \mathrm{S}, 72^{\circ} 10.1^{\prime} \mathrm{W} \\
15^{\circ} 28.5^{\prime} \mathrm{S}, 72^{\circ} 22.9^{\prime} \mathrm{W} \\
15^{\circ} 29.7^{\prime} \mathrm{S}, 72^{\circ} 21.6^{\prime} \mathrm{W}\end{array}$ & $\begin{array}{l}\text { Andesite } \\
\text { Andesite } \\
\text { Andesite }\end{array}$ & $\begin{array}{l}1.78 \\
2.09 \\
1.57^{*}\end{array}$ & $\begin{array}{l}9.369 \\
2.208 \\
3.057\end{array}$ & $\begin{array}{l}55.5 \\
91.6 \\
96.9\end{array}$ & $\begin{array}{l}1.36 \pm 0.03 \\
0.27 \pm 0.02 \\
0.50 \pm 0.07\end{array}$ \\
\hline $\begin{array}{l}\text { Cotahuasi area } \\
\text { CS-05 } \\
\text { CS-09 }\end{array}$ & $\begin{array}{l}15^{\circ} 14.4^{\prime} \mathrm{S}, 72^{\circ} 51.6^{\prime} \mathrm{W} \\
15^{\circ} 24.4^{\prime} \mathrm{S}, 72^{\circ} 44.8^{\prime} \mathrm{W}\end{array}$ & $\begin{array}{l}\text { Andesite } \\
\text { Andesite }\end{array}$ & $\begin{array}{l}1.57^{*} \\
1.73\end{array}$ & $\begin{array}{l}7.273 \\
6.859\end{array}$ & $\begin{array}{l}45.5 \\
51.8\end{array}$ & $\begin{array}{l}1.19 \pm 0.03 \\
1.02 \pm 0.04\end{array}$ \\
\hline $\begin{array}{l}\text { Pausa area } \\
\text { PA-02 }\end{array}$ & $15^{\circ} 15.1^{\prime} \mathrm{S}, 73^{\circ} 25.0^{\prime} \mathrm{W}$ & Andesite & $1.97^{*}$ & 12.43 & 45.7 & $1.62 \pm 0.03$ \\
\hline $\begin{array}{l}\text { Cuzco area } \\
\text { CZ-02-02 } \\
\text { CZ-04 }\end{array}$ & $\begin{array}{l}14^{\circ} 10.1^{\prime} \mathrm{S}, 71^{\circ} 22.2^{\prime} \mathrm{W} \\
13^{\circ} 37.1^{\prime} \mathrm{S}, 71^{\circ} 42.3^{\prime} \mathrm{W}\end{array}$ & $\begin{array}{l}\text { Shoshonite } \\
\text { Andesite }\end{array}$ & $\begin{array}{l}3.56^{*} \\
3.20^{*}\end{array}$ & $\begin{array}{l}0.2575 \\
<8.7\end{array}$ & $\begin{array}{l}100 \\
100\end{array}$ & $\begin{array}{l}<0.027 \\
<0.7\end{array}$ \\
\hline $\begin{array}{l}\text { Puno area } \\
\text { PU-01 } \\
\text { PU-02-02 } \\
\text { PU-03 } \\
\text { PU-04 } \\
\text { PU-05 } \\
\text { PU-06 }\end{array}$ & $\begin{array}{l}15^{\circ} 49.2^{\prime} \mathrm{S}, 70^{\circ} 04.5^{\prime} \mathrm{W} \\
15^{\circ} 49.0^{\prime} \mathrm{S}, 70^{\circ} 04.8^{\prime} \mathrm{W} \\
15^{\circ} 47.4^{\prime} \mathrm{S}, 70^{\circ} 07.1^{\prime} \mathrm{W} \\
15^{\circ} 48.6^{\prime} \mathrm{S}, 70^{\circ} 05.7^{\prime} \mathrm{W} \\
15^{\circ} 49.8^{\prime} \mathrm{S}, 70^{\circ} 04.2^{\prime} \mathrm{W} \\
15^{\circ} 49.0^{\prime} \mathrm{S}, 70^{\circ} 01.7^{\prime} \mathrm{W}\end{array}$ & $\begin{array}{l}\text { Shoshonite } \\
\text { Shoshonite } \\
\text { Shoshonite } \\
\text { Shoshonite } \\
\text { Shoshonite } \\
\text { Shoshonite }\end{array}$ & $\begin{array}{l}3.02 \\
2.30 \\
2.51 \\
2.51 \\
2.67 \\
2.51\end{array}$ & $\begin{array}{l}70.07 \\
52.10 \\
48.10 \\
57.97 \\
61.37 \\
57.73\end{array}$ & $\begin{array}{l}63.0 \\
73.0 \\
53.3 \\
50.0 \\
77.2 \\
62.4\end{array}$ & $\begin{array}{l}5.97 \pm 0.20 \\
5.82 \pm 0.20 \\
5.05 \pm 0.17 \\
5.94 \pm 0.32 \\
5.91 \pm 0.16 \\
5.92 \pm 0.33\end{array}$ \\
\hline $\begin{array}{l}\text { Acora area } \\
\text { AC- } 03\end{array}$ & $15^{\circ} 52.9^{\prime} \mathrm{S}, 69^{\circ} 54.3^{\prime} \mathrm{W}$ & Basanite & 2.07 & 45.32 & 39.8 & $5.63 \pm 0.08$ \\
\hline $\begin{array}{l}\text { Juli area } \\
\text { JL-02 } \\
\text { JL-11 }\end{array}$ & $\begin{array}{l}16^{\circ} 14.6^{\prime} \mathrm{S}, 69^{\circ} 26.9^{\prime} \mathrm{W} \\
16^{\circ} 15.1^{\prime} \mathrm{S}, 69^{\circ} 18.0^{\prime} \mathrm{W}\end{array}$ & $\begin{array}{l}\text { Andesite } \\
\text { Andesite }\end{array}$ & $\begin{array}{l}3.00 \\
2.16\end{array}$ & $\begin{array}{l}76.52 \\
60.50\end{array}$ & $\begin{array}{l}91.6 \\
31.9\end{array}$ & $\begin{array}{l}6.56 \pm 0.64 \\
7.20 \pm 0.09\end{array}$ \\
\hline $\begin{array}{c}\text { Tarata area } \\
\text { TA-01 } \\
\text { TA-10 }\end{array}$ & $\begin{array}{l}17^{\circ} 07.2^{\prime} \mathrm{S}, 70^{\circ} 24.6^{\prime} \mathrm{W} \\
17^{\circ} 08.7^{\prime} \mathrm{S}, 70^{\circ} 16.5^{\prime} \mathrm{W}\end{array}$ & $\begin{array}{l}\text { Andesite } \\
\text { Andesite }\end{array}$ & $\begin{array}{l}1.61^{*} \\
2.22^{*}\end{array}$ & $\begin{array}{l}20.19 \\
53.77\end{array}$ & $\begin{array}{l}87.9 \\
48.5\end{array}$ & $\begin{array}{l}3.23 \pm 0.50 \\
6.23 \pm 0.10\end{array}$ \\
\hline $\begin{array}{l}\text { Omate area } \\
\text { OM-10 }\end{array}$ & $16^{\circ} 51.2^{\prime} \mathrm{S}, 70^{\circ} 13.4^{\prime} \mathrm{W}$ & Andesite & $2.52^{*}$ & 63.03 & 87.3 & $6.43 \pm 0.20$ \\
\hline $\begin{array}{l}\text { Mazo Cruz area } \\
\text { MC-03 } \\
\text { MC-06 }\end{array}$ & $\begin{array}{l}16^{\circ} 44.9^{\prime} \mathrm{S}, 69^{\circ} 39.1^{\prime} \mathrm{W} \\
16^{\circ} 58.2^{\prime} \mathrm{S}, 69^{\circ} 41.9^{\prime} \mathrm{W}\end{array}$ & $\begin{array}{l}\text { Andesite } \\
\text { Dacite }\end{array}$ & $\begin{array}{l}3.70^{*} \\
4.25^{*}\end{array}$ & $\begin{array}{l}45.97 \\
92.44\end{array}$ & $\begin{array}{l}77.4 \\
77.7\end{array}$ & $\begin{array}{l}3.20 \pm 0.11 \\
5.59 \pm 0.11\end{array}$ \\
\hline $\begin{array}{l}\text { Ayacucho area } \\
\text { c) A-116 }\end{array}$ & $13^{\circ} 18.9^{\prime} \mathrm{S}, 74^{\circ} 21.2^{\prime} \mathrm{W}$ & Rhyolite & 2.92 & 27.81 & 82.9 & $2.45 \pm 0.06$ \\
\hline
\end{tabular}

N.B.

a) $K$ content with an asterisk was determined by the X-ray fluorescence method by S. ARAMAKI. Others were determined by the flame photometry with a Li internal standard.

b) $K$-Ar ages were calculated by using following constants (STEIGER and J̈̈GER, 1977). $\lambda_{e}=0.581 \times 10^{-10} \mathrm{yr}^{-1}, \lambda \beta=4.962 \times 10^{-10} \mathrm{yr}^{-1},{ }^{40} \mathrm{~K} / \mathrm{K}=1.167 \times 10^{-4}$ moles $/$ mole.

The uncertainty in the calculated age represents one standard deviation.

c) The sample A-166 belongs to the Scencca group, which is considered to underlie the Barroso group. 
of Quaternary in age. Furthermore, more than one third of analysed samples show ages which exceed $5 \mathrm{Ma}$. If we adopt these ages as their eruption time, those rocks should be assigned in upper Miocene stratigraphically. BELLON and LEFÈVERE (1976) also reported two examples in which samples of the Barroso Group show K-Ar ages of more than $4 \mathrm{Ma}$.' WeIBEL et al. (1978) reported a $\mathrm{K}-\mathrm{Ar}$ age of $5.3 \mathrm{Ma}$ for a volcanic rock of probably Barroso Group which was collected at the foot of Coropuna volcano. These examples suggest that the volcanic rocks which have been assigned to the Barroso Group include much wider age ranges than had been assigned to Quaternary. This may require some modification in the stratigraphy as indicated in Fig. 2. In such an area where volcanic materials almost cover, volcanic morphology is often used to estimate the period of eruption. Present results have revealed, however, that they do not always show good estimates owing to different weathering condition and other factors. Hence, at least some radiometric ages are required to monitor the estimated age.

As long as the present samples are concerned, we can observe some regional differences in the apparent volcanic activities. As shown in Fig. 3, the samples collected from the north western part of Arequipa, located in the area around $15-17.5^{\circ} \mathrm{S}, 71.5-73^{\circ} \mathrm{W}$, show $\mathrm{K}-\mathrm{Ar}$ ages of less than 1-2Ma, whereas those collected from the eastern part of Arequipa such as the Puno, Juli and Mazo Cruz areas show K-Ar ages of late Tertiary. Hence, there is a possibility that the main volcanic activity in the southeastern part of southern Peru was older compared with that in the northwestern part such as the Andahua and Arequipa areas. As an example for a relatively young age of a sample in the southeastern part, a biotite sample in an

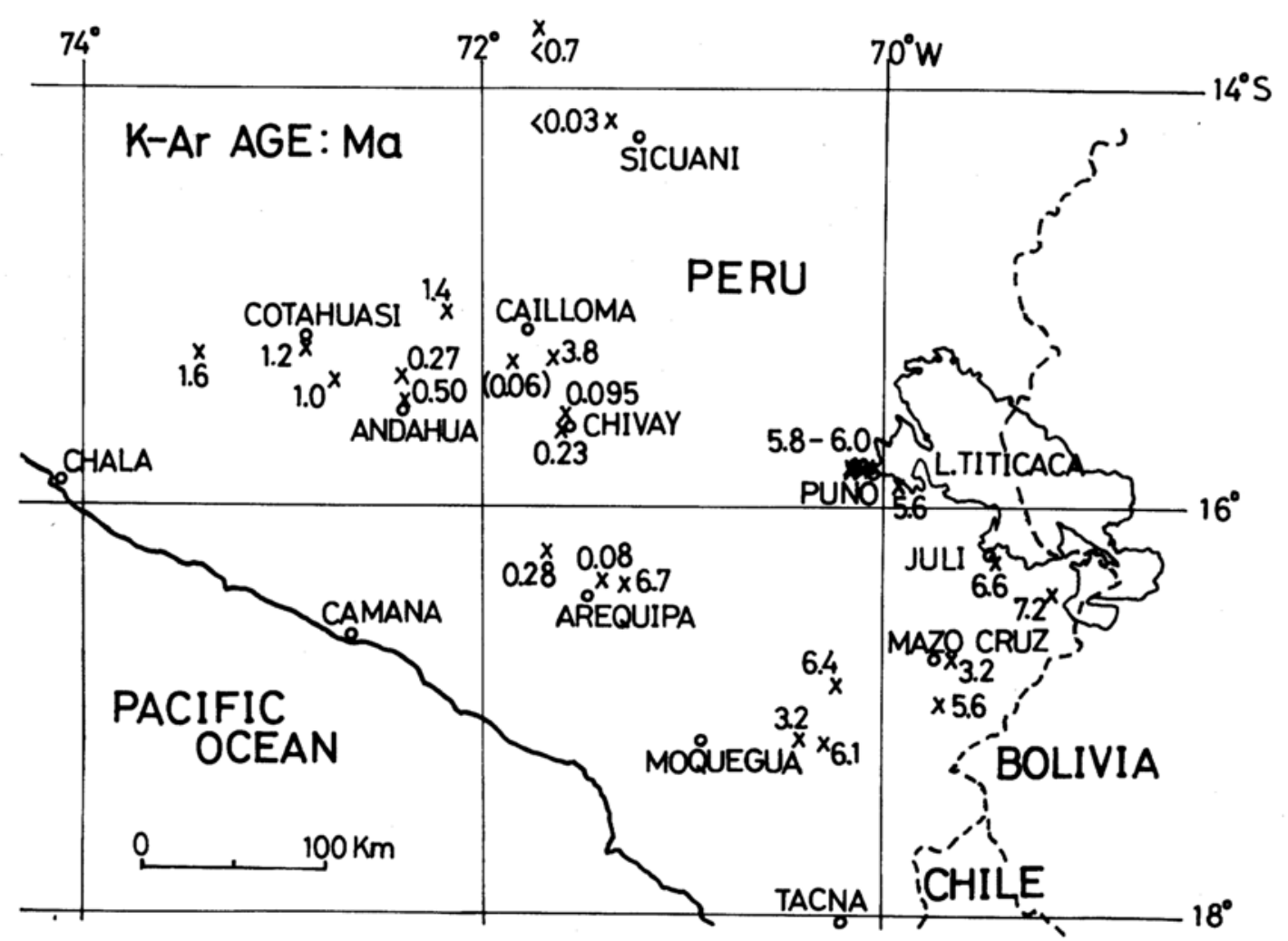

Fig. 3. $\mathrm{K}$-Ar ages (Ma) determined in the present study. Note that relatively young ages of less than $1 \mathrm{Ma}$ are found for rocks collected from the northwestern part of this area including the vicinity of Arequipa, whereas the samples collected from the southeastern part show ages of late Tertiary in most cases. 
andesite collected from the northwestern foot of Tutupaca volcano is reported to show a $\mathrm{K}-\mathrm{Ar}$ age of about $0.7 \mathrm{Ma}$ (TosDAL et al., 1979). The sample was collected from the Tarata area which is located between Moquegua and Mazo Cruz in Fig. 3. In the present study, we discarded such samples which contained large phenocrysts including biotites. One may argue that young samples in the southeastern part in this region might have been systematically dismissed during such a procedure. However, we have no reason to believe that relatively young volcanic rocks contain large phenocrysts systematically. Hence, we think the regional difference in the volcanic activity observed in the present study would be real.

In the surveyed areas in the present study, the youngest volcanic activity occurs along the northwestern edge of the Cordillera Occidental. Present results suggest, however, that very young volcanic activity is observed even in a rather inner continental side such as the Cuzco area as revealed by the data $\mathrm{CZ}-02-02$ and $\mathrm{CZ}-04$. On the other hand, no such young volcanic activity is observed in the Puno and Juli areas on the southern coast of the Lake Titicaca. Hence, the volcanic activity in the Cuzco area seems to have occurred in a special condition. In this context, it may be worth mentioning that the depth of the upper part of the subducted slab in the Cordillera Occidental is estimated to be about $100 \mathrm{~km}$ and that in the Cuzco area around 125$150 \mathrm{~km}$, which are not so different in spite of the surface distance of more than $200 \mathrm{~km}$ (Hasegawa and SACKS, 1981). It is considered that such phenomenon can be explained if the subducted slab becomes almost horizontal having a very small dip angle (HASEGAwA and SACKS, 1981). Such areas extend to the northwestern part of the central Andes and no young volcanic activity is observed there. In the Cuzco area, the slab seems to subduct with a steeper dip angle again (HaSEgawA and SACKS, 1981). Hence, apparently it seems to be necessary for a subducted slab to have some degree of dip angle to cause a volcanic activity, though the detailed mechanism is not yet clear.
In the nothwestern part of the Puno area, there are some hills which are composed of shoshonitic rocks. Although the definition to shoshonitic rocks is rather diverse among different investigators, LEFÈvRE (1973) considered those in the area as a kind of calc-alkaline rocks highly enriched in potassium. Although they were believed to belong to the Barroso Group on the basis of volcanic morphology, K-Ar dating results have revealed that they erupted about $6 \mathrm{Ma}$ ago. All samples were collected from different hills, but all of them are located within the distance of about $20 \mathrm{Km}$. The sample PU03 shows a little younger age than those of the other five hills. However, all the other five samples show quite similar ages of $5.9 \pm 0.1 \mathrm{Ma}$. Although we cannot deny a possibility that the hill from which the sample PU-03 was collected alone erupted about $0.8 \mathrm{Ma}$ later than the other hills, we believe it more likely that the shoshonitic rocks erupted rather in a short period of less than a few hundred thousand years. In effect, the sample PU-03 is not completely fresh. BELLON and LEFÈVRE (1976) also reported a K-Ar age of $5.7 \pm 0.3 \mathrm{Ma}$ for one sample in the Puno area, which is consistent with the present results. Such information on the distribution and the eruption period of shoshonitic rocks implies that they might require some very limited conditions to be formed.

Thus, present results strongly suggest that stratigraphically assigned ages are not sufficient to infer the period of volcanic activity in southern Peru, central Andes. In order to reveal the finer structure of the volcanic activity in space and time in the central Andes, additional radiometric ages would be indispensable.

Acknowledgements-The samples used in this study were collected by the scientific team on "Geochemical investigation of the central Andean volcanic zone" under the auspice of the Overseas Scientific Research, Ministry of Education during the summer of 1980 . The team was composed of the members, N. ONUMA (Leader), S. aramaki, N. FujiI, A. Hasegawa, K. Notsu and one of the authors (I.K.). We appreciate them for their generosity to spare the samples for the present study. J. A. Laho, M. Montoya and F. Portillo also 
assisted us in collecing samples.

\section{REFERENCES}

BAKER, M. C. W. (1977) Geochronology of Upper Tertiary volcanic activity in the Andes of North Chile. Geol. Rundsch. 66, 455-456.

BAKER, M. C. W. and FrANCIS, P. (1978) Upper Cenozoic volcanism in the central Andes - Ages and volumes. Earth Planet. Sci. Lett. 41, 175-187.

BELLON, H. and LEFÈVRE, C. (1976) Données géochronométriques sur le volcanisme andin dans le sud du Pérou. Implications volcano-tectoniques. $C . R$. Acad. Sci. Paris 283, Ser. D, 1-4.

Damon, P. E., Laughlin, A. W. and Percious, J. K. (1967) Problem of excess argon-40 in volcanic rocks. Int. Atomic Energy Agency, Vienna, 463481.

DRAKE, R. E. (1976) Chronology of Cenozoic igneous and tectonic events in the central Chilean Andes - latitudes $35^{\circ} 30^{\prime}$ to $36^{\circ} \mathrm{S}$. J. Volcanol. Geotherm. Res. 1, 265-284.

FARRAR, E. H., ClARK, S. J., HAYNES, G. S., QUiRT, H., ConN, H. and Zentilli, M. (1970) K-Ar evidence for the post-Paleozoic migration of granitic intrution foci in the Andes of northern Chile. Earth Planet. Sci. Lett. 10, 60-66.

HaSegawA, A. and SACKS, I. S. (1981) Subduction of the Nazca plate beneath Peru as determined from seismic observations. J. Geophys. Res. 86, 49714980.

KANEOKA, I. and TAKAOKA, N. (1980) Rare gas isotopes in Hawaiian ultramafic nodules and volcanic rocks: constraint on genetic relationships. Science 208, 1366-1368.

LEFÈVRE, C. (1973) Les caractères magmatiques du volcanisme plio-quaternaire des Andes dans le Sud du Pérou. Contrib. Mineral. Petrol. 41, 259-272.

Noble, D. C., MCKeE, E. H., FARrar, E. and PeterSON, V. (1974) Episodic Cenozoic volcanism and tectonism in the Andes of Peru. Earth Planet. Sci. Lett. 21, 213-220.

SCHWAB, K. and LIPPOLT, H. (1976) K-Ar mineral ages and late Cenozoic history of the Solar de Cauchari area (Argentina Puna). In Proc. Symp. Andean and Antarctic volcanology problems (ed. 0. GONZALES-FERRA), 698-714. Santiago, Chile.

STEIGER, R. H. and JÄGER, E. (1977) Subcommission on geochronology: Convention on the use of decay constants in geo- and cosmo-chronology. Earth Planet. Sci. Lett. 36, 359-362.

Stewart, J. W., Evernden, J. F. and Snelling, N. J. (1974) Age determinations from Andean Peru: A reconnaissance Survey. Geol. Soc. Am. Bull. 85, $1107-1116$.

THORPE, R. S. and FranCIS, P. W. (1979) Variations in Andean andesite compositions and their petrogenetic significance. Tectonophysics 57, 53-70.

ToSDAL, R. M., FARrar, E. and Clark, A. H. (1979) $\mathrm{K}$-Ar geochronology of the late Cenozoic volcanic rocks of the Cordillera Occidental, southernmost Peru. J. Volcanol. Geotherm. Res. 10, 157-173. WEIBEL, VON M., FRANGIPANE-GYSEL, M. and HUNZIKER, J. (1978) Ein Beitrag zur Vulkanologie Süd-Perus. Geol. Rundsch. 67, 243-252. 